\title{
TRANSLITTÉRATIONS DES CARACTÈRES ARABES $^{1}$
}

\begin{tabular}{|c|c|}
\hline ال (article), al- et 1- & ش: sh \\
\hline Voyelles longues : $\overline{\mathrm{a}}, \overline{\mathrm{u}}, \overline{\mathrm{l}}$ & S : ص ص \\
\hline$ء:$ & 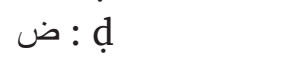 \\
\hline : b & $b: t$ \\
\hline$ت: t$ & ظ: z \\
\hline$ث:$ th & $\varepsilon: ‘$ \\
\hline ج: & $\dot{\varepsilon}: g h$ \\
\hline$\tau: h$ & $\dot{\omega}:$ f \\
\hline$\dot{\tau}: \mathrm{kh}$ & ق: q \\
\hline$د: d$ & s) : $\mathrm{k}$ \\
\hline$\dot{j}: \mathrm{dh}$ & J:1 \\
\hline$\jmath: r$ & ค: m \\
\hline$j: z$ & ن:n \\
\hline س :s & : : h, و، ي \\
\hline
\end{tabular}

${ }^{1}$ Les noms arabes translittérés ne portent pas de majuscule ni de $s$ au pluriel (exemple : les mu'minūn), voir, note 21 . 
